SPIES AND SCHOLARS 



\section{SPIES AND SCHOLARS}

Chinese Secrets and Imperial Russia's Quest for World Power

\section{GREGORY AFINOGENOV}

THE BELKNAP PRESS OF HARVARD UNIVERSITY PRESS Cambridge, Massachusetts \& London, England 


\section{Copyright $\odot 2020$ by Gregory Afinogenov} All rights reserved Printed in the United States of America

First printing

Cover illustration: Qing soldiers, from a caravan journal, 1736 Cover design: Annamarie McMahon Why

$$
\begin{array}{r}
9780674246577 \text { (EPUB) } \\
9780674246584(\mathrm{MOBI}) \\
9780674246591 \text { (PDF) }
\end{array}
$$

The Library of Congress has cataloged the printed edition as follows:

Names: Afinogenov, Gregory, author. Title: Spies and scholars : Chinese secrets and Imperial Russia’s quest for world power / Gregory Afinogenov. Description: Cambridge, Massachusetts : The Belknap Press of Harvard University Press, 2020. | Includes bibliographical references and index.

Identifiers: LCCN 2019045276 | ISBN 9780674241855 (cloth)

Subjects: LCSH: Espionage, Russian-China-History. | Intellectuals-Russia-Attitudes. | East and West. | China-Study and teaching-Russia-History. Classification: LCC DS734.97.R8 A35 2020 | DDC 327.124705109/ 032-dc23

LC record available at https://lccn.loc.gov/2019045276 
For my parents 
